\title{
Family factors and personality factors affecting daily SNS usage in individuals aged 14-19 years
}

\author{
Czynniki rodzinne i osobowościowe a długość czasu korzystania z portalu społecznościowego przez \\ osoby w wieku 14-19 lat
}

\author{
Beata Pawłowska ${ }^{1}$ ABCDE https://orcid.org/0000-0003-3520-0187, \\ Agnieszka Dyzma² BF
}

${ }^{1}$ II Department of Psychiatry and Psychiatric Rehabilitation, Medical University of Lublin, Poland ${ }^{2}$ Student of the Medical University of Lublin, Poland

\begin{abstract}
Introduction: In recent years, social networking sites (SNS), such as Facebook, Twitter or Instagram have gained immense popularity and have become an essential part of many people's everyday lives. In Poland, 19 million people, i.e. about a half of the whole population, are active SNS users.

Aim: The aim of the present study was to analyze the relationship of family and personality factors with daily SNS usage time in adolescents aged 14 to 19 years.

Participants: The study included 291 junior-high and high school students aged 14-19 years. In this sample, 246 individuals had an SNS profile.

Methods: The following instruments were used: an Inquiry Form designed by the present authors, Gough and Heilbrun's Adjective Check List, the Coping with Stress Questionnaire by Janke, Erdmann and Boucsein and the Buss and Durkee HostilityGuilt Inventory.

Results: Based on correlation coefficients, significant associations were found between increased daily SNS usage and negative relationships with parents, maladaptive coping, and increased aggression.

Conclusions:

1. Participants who spent more time using SNS were more likely to feel lonely in their families and have a sense of not being accepted and understood by their parents.

2. Young people who spent more time using SNS were more likely to respond to a stressful situation with a sense of helplessness and resignation and to cope by downplaying their problems and seeking substitute gratification or support.

3. Young people who spent more time using SNS were more likely to respond with indirect aggression, negativism, suspicion, hostility and verbal aggression.
\end{abstract}

Keywords: social networking sites, adolescents, personality traits

\section{Streszczenie}

Wstęp: W ciągu ostatnich lat korzystanie z portali społecznościowych (SNS, ang. social networking sites), takich jak np.: Facebook, Twitter i Instagram, zyskało ogromną popularność i stało się dla wielu osób niezbędnym elementem każdego dnia. Aktywnymi użytkownikami mediów społecznościowych jest 19 milionów Polaków, czyli około połowa populacji naszego kraju. Cel: Celem pracy była analiza zależności między czynnikami rodzinnymi i osobowościowymi a długością czasu korzystania z portalu społecznościowego przez młodzież w wieku od 14 do 19r.ż.

Grupa badana: Badaniami objęto 291 uczniów gimnazjów i liceów (188 dziewcząt i 103 chłopców) w wieku od 14 do 19 roku życia. W tej grupie młodzieży 246 miało profil na portalu społecznościowym. Średni wiek badanych wynosił 16,5 lat.

Metody: W pracy zastosowano metody badawcze: ankietę własnej konstrukcji, Test Przymiotnikowy ACL Gougha i Heilbruna, Kwestionariusz Radzenia Sobie ze Stresem autorstwa Janke, Erdman, Boucsein oraz Kwestionariusz „Nastroje i Humory” Buss, Durkee. 
Wyniki: Na podstawie wyników korelacji stwierdzono występowanie istotnych zależności między dłuższym czasem korzystania z portalu społecznościowego przez badanych a negatywnymi relacjami z rodzicami, nieadaptacyjnymi sposobami radzenia sobie ze stresem oraz nasiloną agresją.

Wnioski:

1. Dłuższy czas korzystania z SNS przez młodzież łączy się z poczuciem osamotnienia w rodzinie, braku akceptacji i zrozumienia ze strony rodziców.

2. Dłuższy czas korzystania z SNS przez młodzież łączy się z reagowaniem w sytuacji stresu poczuciem bezradności, rezygnacji, bagatelizowaniem problemów, poszukiwaniem zastępczej satysfakcji lub wsparcia.

3. Dłuższy czas korzystania z SNS łączy się z częstym reagowaniem agresją pośrednią, negatywizmem, podejrzliwością, wrogością oraz agresją słowną.

Słowa kluczowe: portale społecznościowe (SNS), młodzież, cechy osobowości

\section{Introduction}

In recent years, social networking sites (SNS), such as Facebook, Twitter or Instagram have become immensely popular, to the point of becoming an essential part of many people's everyday lives. SNS are Internet services that perform multiple functions: they facilitate communication, provide entertainment, and serve as marketing tools and sources of information. The latest data show that 19 million Poles, i.e. about a half of the country's population, are active SNS users. They spend an average of two hours a day using social media [1,2]. Pempek et al. [3] found that the time students spent using Facebook was scattered throughout the day, which suggested that their Facebook activity was an inherent part of their daily life.

It should be emphasized here that the increase in the time young people spend daily using the Internet, including SNS, may be due to the current pandemic situation, repeated lockdowns, distance learning, limited face-to-face interactions with peers, and the fact that students spend most of their days at home with their family instead of spending it at school with their schoolmates and friends. Face-to face social and professional interactions at work, at school and outside those institutions have been heavily, if not completely, restricted and relegated to the Internet. Teachers, educators, and school psychologists call attention to the fact that some students turn off their webcams during classes to play games, communicate via social media or instant messages. Specialists emphasize that restricted face-to-face social interactions and the transfer of the school to the Internet have had negative effects on children and adolescents. A child who previously studied under the supervision of a teacher at school, is now often left unsupervised and unattended at home, as the parents have to be at work during school hours. Some parents try to minimize the negative impact of the pandemic situation on their children as much as they can, while others believe that their children will "cope on their own just the way they used to", or neglect the children altogether, showing no interest in their problems. Children and adolescents who have found themselves in such a situation, isolated from their peers and not receiving help from outside the family, may try to escape from the difficult situation into the virtual world and online social interactions. In this light, it is particularly important that researchers investigate both family and personality factors that may contribute to excessive, pathological use of SNS.

There are plenty of studies on the impact of SNS on an individual's life. Lanigan [4], however, believes that there is still too little current research that would explain the correlations between the use of SNS and the functioning of the family, communication between family members, and the quality of their mutual relationships. MartínezFerrer et al. [5] reported that problematic use of SNS by family members led to social isolation among adolescents and restricted or disturbed communication between family members, as well as being associated with high levels of child-parent violence. Ali and Lodhi [6] observed numerous conflicts, weaker family ties, relationship breakdown and a low level of interest in siblings in families of students addicted to Facebook. Similarly, Huisman et al. [7] noted that the use of SNS could lead to conflicts in families. In their opinion, the misunderstandings might be due to differences in family members' views on the role of technology, the length of time young people can spend using SNS, the ways SNS are used and their impact on children. Iovu et al. [8] showed that a high level of activity of family members on Facebook had a negative impact on the level of their satisfaction with life. A contrasting finding was reported by Sharaievska and Stodolska [9], who observed that the use of SNS increased a family's satisfaction, allowing family members to stay in touch with more distant relatives and develop a sense of community.

Very few authors have analyzed the personality types of people who are frequent SNS users or their motivation to use social media. Nadkarni and Hofmann [10] believe that frequent use of SNS is associated with an increased level of extroversion, neuroticism and narcissism, as well as low self-esteem. Facebook users 
who had high extroversion and self-esteem scores showed a higher level of gregariousness and were members of a larger number of Facebook interest groups, compared to introverts $[11,12]$. People who have few offline friends usually compensate for their introversion, limited number of social interactions, low self-esteem and low life satisfaction by using Facebook [13-16]. Orr et al. [17] believe that Facebook and MySpace give shy people the opportunity to engage in social interactions that they might otherwise avoid. The level of timidity is especially related to the amount of time individuals spend using Facebook and it positively correlates with their attitudes towards the people with whom they keep in touch via social media. Timidity is negatively correlated with the number of Facebook friends. Because it is easy to establish relationships via SNS, timid individuals tend to spend more time using those sites, which may result in excessive and/or potentially addictive use of SNS [18]. In a sample of university students, intense engagement in Facebook activity reduced the level of the participants' perceived loneliness and had a positive impact on their social lives. A positive correlation was observed between the amount of time spent on Facebook activity and the number of offline friends [18]. Yu et al. [19] observed a positive correlation between Facebook activity and improved self-esteem in the university students they surveyed in China. In their opinion, Facebook use was primarily determined by an increased need for belonging and self-presentation. The need to belong is defined as a motivation to gain social acceptance. It can be influenced by SNS users' personality traits, such as narcissism, neuroticism, introversion, extroversion, self-esteem, self-worth, and timidity. Selfworth and self-esteem are closely related to the need for belonging and often reflect a person's social acceptance. Back et al. [20], Livingstone [21] believe that Facebook users set up their profiles to project a perfect image of the self. Potembska et al. [22] found in their study that adolescents who had an SNS profile had a more negative self-image compared to adolescents who did not have such a profile. Boys who had an SNS profile, compared to their peers without an SNS profile, expressed increased hostility towards themselves and others, were less selfconfident, had less insight into their own and other people's motives, tended to break rules and social norms, were more impulsive, less responsible, less enterprising, less persistent in carrying out their tasks, and showed less tolerance to frustration. Girls with an SNS profile, compared to their peers without an SNS profile, had greater difficulty coping with stress, an increased tendency to escape from reality into dreams, and a significantly more intense need for support, care, attention and help; at the same time, they perceived other people as being stronger, more competent and more effective than themselves [22].
Andreassen and Pallesen [23] believe that the most likely risk factors for developing addiction to SNS are personality traits, needs and self-esteem. People who are addicted to the Internet often find it difficult to establish close or intimate relationships with others in real life and therefore may prefer to engage in online interactions to connect with others in a way that does not pose a threat to them [24]. Such people can create new virtual relationships or nurture existing ones as they engage in regular interactions by frequently visiting SNS. Virtual communities such as Facebook and other SNS often form a social support network, which can help users meet the need for establishing social relationships [25]. People who have trouble developing proper interpersonal relationships in real life often learn that they can communicate comfortably in a virtual environment and find the acceptance and companionship they lack. Therefore, these people may be motivated to use SNS more often as an alternative way of establishing social relations [26].

It should also be emphasized that now, one year into the SARS-CoV-2 pandemic, during which young people in Poland and all over the world have participated in distance learning, had only limited face-to-face contacts with their peers and, instead, interacted with them mainly via the Internet, staying "locked down" at home, and therefore engaging in more interactions with their parents, research investigating the relationships of family and social factors with the increased time young people spend using SNS may be particularly valuable. Findings from this research, apart from being of theoretical interest, may also have practical implications. They can be used in planning measures to prevent children and adolescents' misuse of the Internet, including SNS.

\section{Aim}

The aim of the present study was to analyze the relationship between the amount of time the participants spent daily using SNS and selected family and personality factors (self-image characteristics, coping styles and types of the aggression syndrome).

\section{Hypotheses}

The following research hypotheses were formulated:

1. There are significant associations between the participants' daily SNS usage time and alcohol abuse by a family member, domestic violence, and a lack of parental acceptance.

2. There are significant associations between the participants' daily SNS usage time and their negative self-image.

3. There are significant associations between the participants' daily SNS usage time and seeking 
substitute gratification in response to stress.

4. There are significant associations between the participants' daily SNS usage time and indirect aggression.

\section{Material}

The study included 291 junior-high school and high school students (188 girls and 103 boys) aged 14-19 years. The participants' mean age was 16.5 years ( $S D=1.48)$. One hundred and thirty two (132) of the youngsters taking part in the study came from towns or cities and 159 came from the countryside. Among the junior-high school students, there were 59 girls and 44 boys, and among the high school students, there were 129 girls and 59 boys. Two hundred and forty seven (247) of the students surveyed were being brought up in a nuclear family, 35 in a single-parent family, and 8 in a reconstructed family. Among the participants' parents, 74 mothers and 42 fathers had higher education, 126 mothers and 116 fathers had secondary education, 66 mothers and 102 fathers had vocational education, and 19 mothers and 18 fathers had primary education. Of these, 213 mothers and 226 fathers were economically active. Ten (10) mothers and 19 fathers received a disability pension, and 12 mothers and 6 fathers were old age pensioners. Twenty (20) of the fathers and 54 of the mothers were unemployed. Among the participants, 262 had siblings. Fifty one (51) of the students (including 34 students aged 14-17) were smokers, 254 (including 177 students aged 14-17) drank alcohol, and 34 used drugs. Thirty two (32) participants reported alcohol abuse by a family member. Six (6) mothers and 20 fathers abused alcohol.

\section{Methods}

The following measures were used:

An Inquiry Form developed by the present authors was used to collect sociodemographic data and to determine the amount of time (in hours) the participants spent daily using SNS, their parents' education level, and the quality of relationships in the family (sense of loneliness, sense of parental acceptance and understanding, sense of parental disappointment, experiences of psychological and/or physical abuse by parents, experiences of parental conflicts, and alcohol abuse by parents).

The Adjective Check List (ACL) by Gough and Heilbrun had been developed at the Institute of Personality Assessment and Research at the University of California, Berkley. It is a list of 300 adjectives that is most often used as a multi-scale personality test in which the participants describe themselves by marking those adjectives they consider self-descriptive. The 1980 version of the ACL consists of 37 scales divided into five groups: I. Modus Operandi Scales, II. Need Scales (based on Murray's
Need-Press theory of personality), III. Topical Scales, IV. Transactional Analysis Scales (based on Berne's Transactional Analysis theory of personality), and V. Origence-Intellectence Scales. The reliability of the ACL had been assessed taking into account its various aspects. In a group of 100 men who completed the ACL twice, approximately 6 months apart, the individual stability coefficients ranged from +0.01 to +0.54 [27]. To determine the reliability of the individual scales, the ACL was administered twice, 10 weeks apart, in a sample of 56 men. The correlation coefficients obtained in that study ranged from 0.54 to 0.85 . The reliability of the Polish translation of the ACL was tested in a similar way. External validity criteria were used: ACL scores were correlated with scores obtained from the following measures: the Edwards Personal Preference Schedule, the MMPI, the Thematic Apperception Test, and the California Psychological Inventory [27].

The Stress Coping Style Questionnaire (SVF) by Janke, Erdman and Boucsein was translated and adapted into Polish by Januszewska [28]. SVF consists of 114 items testing 19 coping strategies, as listed below: Minimization, Self-Aggrandizement, Denial of Guilt, Substitute Gratification, Search for Self-Affirmation, Situation Control, Response Control, Positive Self-Instructions, Need for Social Support, Avoidance, Escape, Social Withdrawal, Rumination, Resignation, Self-Pity, Self-Blame, Aggression, and Drug Use. The questionnaire had been developed with a Polish sample, which consisted of 268 girls and 204 boys aged from 13 to 18 years. Cronbach's alpha for all the 114 items was 0.94 and Cronbach's alpha for the 19 coping strategies was $\alpha=0.88$ [28].

The Buss and Durkee Hostility-Guilt Inventory (HGI) had been developed in 1957. It consists of 75 original items, 66 of which are used to rate different types of aggressiveness and hostility, and 9 are designed to measure guilt. The reliability coefficients for the scales measuring different types of aggressiveness ranged from 0.78 to 0.61 , and only the reliability coefficient for the Negativism Scale was lower at 0.46 . The authors of the Inventory evaluated the theoretical and factor validity of the method, by distinguishing seven types of aggressive reactions, which they grouped into two classes called Aggressiveness and Hostility. The Polish version of the questionnaire, entitled Moods and Humors was prepared by Choynowski [29]. The questionnaire contains the following scales: Physical Aggression, Verbal Aggression, Indirect Aggression, Negativism, Suspicion, Resentment, Irritability, and Guilt. The H-GI can be administered to both individuals and groups. The sum of points for scales I-VII is the "General Aggression" score. The Polish adaptation of the H-GI was developed with a sample of 284 persons. 


\section{Results}

In the first step of the analysis based on the survey data from the Inquiry Form, 246 individuals were selected from the entire group of 291 students who had a profile on an SNS. Out of the 103 male and 188 female participants, 74 boys and 171 girls reported having an SNS profile.
To test Hypothesis 1, Point-biserial correlation coefficient were calculated between the number of hours the participants spent daily on SNS and the family factors identified using the Inquiry Form. The data were analyzed by gender (Table 1). The table shows statistically significant results

Table 1. Correlation coefficients between daily SNS usage (in hours) and family factors

\begin{tabular}{|l|c|c|c|}
\hline Family factors & Entire group & Males & Females \\
\hline Father's education level & & $-0.28^{*}$ & $0.17^{*}$ \\
\hline $\begin{array}{l}\text { Alcohol abuse by a family } \\
\text { member }\end{array}$ & $0.14^{*}$ & $-17^{*}$ \\
\hline $\begin{array}{l}\text { Sense of being lonely in } \\
\text { the family }\end{array}$ & $-0.21^{* * *}$ & $-0.16^{*}$ & $-0.23^{* *}$ \\
\hline $\begin{array}{l}\text { Sense of parental } \\
\text { acceptance }\end{array}$ & $-0.15^{*}$ & $-0.28^{*}$ & $0.16^{*}$ \\
\hline $\begin{array}{l}\text { Sense of maternal } \\
\text { acceptance }\end{array}$ & $-0.15^{*}$ & & $0.16^{*}$ \\
\hline Conflicts with parents & & & \\
\hline $\begin{array}{l}\text { Psychological abuse by } \\
\text { parents }\end{array}$ & & & \\
\hline $\begin{array}{l}\text { Sense of being } \\
\text { understood by the } \\
\text { mother }\end{array}$ & & & $0.23^{* *}$ \\
\hline $\begin{array}{l}\text { Sense of having } \\
\text { disappointed the mother }\end{array}$ & & & \\
\hline
\end{tabular}

Notations: ${ }^{*} p<0.05 ;{ }^{* *} p<0.01 ;{ }^{* * *} p<0.001$

In the entire sample, there were significant associations between longer times spent using SNS and the sense of being lonely in the family and not being accepted and understood by parents, mainly the mother. In the group of male participants, significant correlations were found between longer daily SNS usage times and the father's lower level of education, a sense of parental lack of acceptance, and loneliness in the family. In the group of female participants, significant correlations were found between longer daily SNS usage times and alcohol abuse by parents, parental conflicts, experiences of psychological abuse by parents, a sense of loneliness in the family, lack of acceptance and understanding by the mother, and maternal disappointment.

In the next stage of the study, we analyzed the relationships between the length of time the respondents spent using SNS and the following personality factors: self-image, coping styles and aggression types.

To test Hypothesis 2, Pearson's correlation coefficients ( $r$ ) were calculated between the amount of time the respondents spent daily using SNS and their ACL scores (Table 2).

Table 2. Correlation coefficients between the participants' daily SNS usage times and their ACL scores

\begin{tabular}{|l|c|c|c|}
\hline ACL scales & Entire group & Males & Females \\
\hline $\begin{array}{l}\text { Total number adjectives } \\
\text { checked }\end{array}$ & -0.02 & -0.01 & 0.02 \\
\hline $\begin{array}{l}\text { Number of favorable } \\
\text { adjectives }\end{array}$ & 0.05 & 0.04 & 0.02 \\
\hline $\begin{array}{l}\text { Number of unfavorable } \\
\text { adjectives }\end{array}$ & -0.07 & -0.24 & -0.08 \\
\hline Communality & -0.06 & 0.02 & -0.10 \\
\hline Need for achievement & -0.09 & -0.06 & 0.00 \\
\hline Need for dominance & 0.00 & 0.02 & 0.02 \\
\hline
\end{tabular}




\begin{tabular}{|l|c|c|c|}
\hline Need for endurance & 0.04 & 0.10 & -0.02 \\
\hline Need for order & 0.02 & 0.04 & -0.03 \\
\hline Need for intraception & -0.03 & -0.05 & -0.05 \\
\hline Need for nurturance & 0.01 & 0.16 & -0.03 \\
\hline Need for affiliation & 0.01 & 0.08 & 0.00 \\
\hline Need for heterosexuality & 0.11 & 0.24 & 0.09 \\
\hline Need for exhibition & -0.07 & -0.03 & -0.05 \\
\hline Need for autonomy & -0.03 & -0.24 & 0.07 \\
\hline Need for aggression & 0.01 & -0.08 & 0.06 \\
\hline Need for change & 0.03 & 0.09 & 0.01 \\
\hline Need for support & -0.01 & 0.12 & -0.05 \\
\hline Need for abasement & 0.02 & 0.11 & -0.08 \\
\hline Need for deference & 0.11 & $0.26^{*}$ & 0.00 \\
\hline Counselling readiness & -0.11 & -0.16 & -0.10 \\
\hline scale & -0.06 & -0.10 & -0.11 \\
\hline Self-control & 0.04 & 0.09 & 0.01 \\
\hline Self-confidence & -0.02 & 0.12 & -0.04 \\
\hline Personal adjustment & 0.07 & 0.24 & 0.01 \\
\hline Idea self scale & 0.04 & -0.09 & 0.12 \\
\hline Creative personality scale & 0.02 & 0.05 & 0.03 \\
\hline Military leadership scale & -0.06 & -0.11 & 0.01 \\
\hline $\begin{array}{l}\text { Masculine attributes } \\
\text { scale }\end{array}$ & -0.02 & -0.06 & 0.03 \\
\hline Feminine attributes scale & -0.01 & -0.12 & -0.05 \\
\hline Critical parent & 0.01 & 0.17 & -0.06 \\
\hline Nurturing parent & -0.03 & 0.03 & 0.10 \\
\hline Adult & 0.03 & 0.03 & 0.07 \\
\hline Free child & -0.05 & & \\
\hline Adapted child & & & \\
\hline & & & \\
\hline
\end{tabular}

Notations: ${ }^{*} p<0.05 ;{ }^{* *} p<0.01 ;{ }^{* * *} p<0.001$

Statistically significant associations were found between longer SNS usage times in boys and their increased need for deference.
To test Hypothesis 3, Pearson's correlation coefficients (r) were calculated between the respondents' daily SNS usage times and their SVF scores (Table 3).

Table 3. Correlation coefficients between the participants' daily SNS usage times and their SVF scores

\begin{tabular}{|l|c|c|c|}
\hline SVF scales & Entire group & Males & Females \\
\hline Belittling & $0.14^{*}$ & 0.07 & 0.11 \\
\hline Comparisons to others & 0.07 & 0.04 & 0.11 \\
\hline Defence against guilt & 0.08 & 0.04 & 0.08 \\
\hline Diverting attention & -0.03 & -0.08 & -0.06 \\
\hline Alternative satisfaction & $0.14^{*}$ & -0.19 & $0.21^{* *}$ \\
\hline Seeking self-affirmation & 0.06 & -0.21 & 0.13 \\
\hline $\begin{array}{l}\text { Attempt to control the } \\
\text { situation }\end{array}$ & 0.06 & -0.10 & 0.10 \\
\hline
\end{tabular}




\begin{tabular}{|l|c|c|c|}
\hline $\begin{array}{l}\text { Attempt to control one's } \\
\text { reactions }\end{array}$ & -0.01 & -0.08 & 0.00 \\
\hline Positive self-instruction & 0.11 & -0.02 & 0.14 \\
\hline Seeking social support & $0.14^{*}$ & 0.07 & 0.10 \\
\hline Avoiding tendency & 0.02 & -0.09 & 0.00 \\
\hline Escaping tendency & 0.09 & 0.02 & 0.06 \\
\hline $\begin{array}{l}\text { Isolation from other } \\
\text { people }\end{array}$ & 0.04 & -0.10 & 0.04 \\
\hline Further preoccupation & 0.08 & -0.01 & 0.05 \\
\hline Resignation & $0.16^{*}$ & -0.01 & 0.13 \\
\hline Self-pity & 0.09 & 0.01 & 0.06 \\
\hline Self-blaming & 0.11 & 0.11 & 0.04 \\
\hline Aggression & 0.11 & -0.03 & 0.13 \\
\hline Addiction & 0.11 & 0.07 & 0.14 \\
\hline
\end{tabular}

Notations: ${ }^{*} p<0.05 ;{ }^{* *} p<0.01 ;{ }^{* * *} p<0.001$

The results for the entire sample showed that there were significant relationships between longer SNS usage times and the use of coping strategies that involved downplaying problems, looking for substitute gratification, turning to other people for support, help, and advice, or a sense of failure, depressed mood, and hopelessness. In the girls' group, longer SNS usage times were significantly associated with coping strategies that consisted in engaging in substitute activities, such as eating, watching TV, shopping, etc. In the group of boys, no significant correlations were found between the investigated variables.

To test Hypothesis 4, Pearson's correlation coefficients (r) were calculated between the respondents' daily SNS usage times and their H-GI scores (Table 4).

The results for the entire sample and for the female

Table 4. Correlation coefficients between the participants' daily SNS usage times and their H-GI scores

\begin{tabular}{|l|c|c|c|}
\hline Hostility-Guilt Inventory & Entire group & Males & Females \\
\hline Physical aggression & 0.09 & 0.02 & $0.25^{* *}$ \\
\hline Indirect aggression & $0.18^{* *}$ & 0.20 & $0.18^{*}$ \\
\hline Irritation & 0.08 & 0.01 & 0.09 \\
\hline Negativism & $0.18^{* *}$ & 0.03 & $0.25^{* * *}$ \\
\hline Resentment & 0.11 & 0.05 & 0.12 \\
\hline Suspiciousness & $0.16^{*}$ & 0.21 & $0.16^{*}$ \\
\hline Verbal aggression & $0.23^{* * *}$ & 0.15 & $0.25^{* *}$ \\
\hline Guilt & 0.06 & 0.00 & 0.04 \\
\hline Aggression total score & $0.25^{* *}$ & 0.20 & $0.25^{* *}$ \\
\hline
\end{tabular}

Notations: ${ }^{*} p<0.05 ;{ }^{* *} p<0.01 ;{ }^{* *} p<0.001$

subsample indicated that there were statistically significant relationships between longer times spent using SNS and indirect and verbal aggression, negativism, suspicion, and hostility. Additionally, in the female group, statistically significant positive correlations were obtained between the participants' daily SNS activity and their increased physical aggressiveness.

\section{Discussion}

The results of the statistical analyses allowed us to verify the research hypotheses formulated in the study. Hypothesis 1 was fully confirmed. The results for the entire sample showed that there were significant associations between longer times spent using SNS and the sense of being lonely in the family and not being accepted and understood by parents, mainly the mother. In the 
group of boys, significant relationships existed between longer SNS usage times and the father's lower level of education and the sense of not being accepted by one's family. In the group of female participants, significant correlations were found between longer daily SNS usage times and alcohol abuse by parents, parental conflicts, experiences of psychological abuse by parents, a sense of loneliness in the family, lack of parental acceptance and understanding, and maternal disappointment. These results are consistent with the opinion expressed by other authors $[4,5,6]$ that families of problematic SNS users are characterized by high levels of violence, impaired communication, numerous conflicts, and breakdown of relationships. In the face of traumatic experiences associated with interactions with abusive, alcoholic parents who do not accept their child, the participants may want to "escape" into the "world of virtual relationships, the world of the Internet", which will allow them to meet their basic psychological needs that are not satisfied in the family. Relationships established via SNS may become a "substitute" for traumatic family relationships, as suggested by the results reported by other authors [22].

Partial confirmation was obtained for Hypothesis 2, which assumed that there existed significant relationships between the participants' daily SNS usage and their self-image characteristics. The male subsample was the only group in which significant correlations were found between longer SNS usage times and an increased need to submit to others and assume subordinate roles in relationships with others. It can be hypothesized that shy people, who have difficulty establishing social relationships in real life, may prefer to engage in interactions with others in a non-threatening manner via the Internet [24]. Such persons can seek new virtual relationships or nurture existing ones via regular interactions on SNS. Virtual communities such as Facebook and other social media allow people to meet the need for social support [25]. By using the chat feature, instant messaging, or general posts and comments, SNS users can communicate with others to compensate for the lack of emotional ties in real life. Subrahmanyam et al. [30] noted that social causes were the most important factor motivating students to use SNS. Nadkarni and Hofmann [10] found that the use of Facebook was determined primarily by the need for belonging, social acceptance and self-presentation. For timid people with an increased need for deference, the Internet may be the only place to create a positive self-image and establish social relationships. This opinion corresponds with that expressed by Back et al. [20] and Livingstone [21], who believe that Facebook users create their profiles to project a perfect image of themselves [20,21]. Pawłowska et al. [31] showed that young people were motivated to set up a profile on an SNS by the desire to stay in contact with friends, acquire new information about them and to brag. Those authors [31] also reported that girls' activity on SNS was associated with self-image characteristics such as increased impulsiveness, the desire to get instant gratification, seeking new stimuli and sensations, greater courage, and self-confidence. Boys' activity on SNS was associated with an increased need for belonging and establishing heterosexual relationships [31].

Our results fully confirmed Hypothesis 3. In the group of male participants, significant relationships were found between longer SNS usage times and the use of coping strategies that involved downplaying problems, looking for substitute gratification, turning to other people for support, help, and advice, or a sense of failure, depressed mood, and hopelessness. In girls, longer SNS usage times were significantly associated with coping strategies that consisted in engaging in substitute activities, such as eating, watching TV, shopping, etc. This shows that the time spent using SNS provides substitute gratification and is a form of coping that helps people to "escape" from problems, "forget" about them, and downplay them. It should be emphasized that people who use the Internet pathologically, use it to "escape from problems, replacing the reality that does not satisfy them with the virtual world of the Internet", which is easy to "mold and create" [22].

The results we obtained confirmed Hypothesis 4, at the same time providing additional information. In the entire sample and in the female subsample, statistically significant relationships were found between longer times spent using SNS and frequent use of indirect and verbal aggression, negativism, suspicion, and hostility. Girls who spent more time using SNS were more likely to frequently display physical aggression. It can be supposed that, for girls, the Internet and SNS provide space where they can express the aggression and anger they cannot vent creatively in the real world, without censorship, cultural restrictions, and fear of consequences.

Summarizing the results of our study, we should emphasize that increased daily SNS usage is promoted by both family factors which adversely affect the proper development of children and adolescents (such as conflicts, violence, alcohol abuse by parents, or lack of parental acceptance and understanding, which all leave the child feeling lonely) and personality factors, mainly maladaptive coping strategies and increased aggression.

When one analyzes the current situation related to the pandemic and the fact that young people have been isolated from their peers for months, that their faceto-face interactions have been limited to the nearest family environment, and that they have been forced to use the Internet daily for long hours to both continue 
their education and keep in touch with others, it is very important to call attention to the risk factors for the development of pathological use of the Internet, including SNS, in children and adolescents, and, if necessary, to provide help to both, them and their families. Psychiatrists and psychologists point out that measures should be taken to prevent the negative impact of the Internet and SNS on the family. According to O'Keeffe [32], these technologies should be used in a more prudent way so that parents can exercise more control over their children's and their own "digital life". She suggests that true family ties can be re-established only if family members learn to use the Internet properly, i.e. if they "disconnect from the network". On the other hand, Reid Chassiakos [33] writes about the necessity to introduce tailored "healthy" media plans for families which would define the limits of using new technologies. An introduction of consistent rules on media use would help family members learn how to properly and openly communicate with one another.

\section{Conclusion}

1. Participants who spent more time using SNS were more likely to feel lonely in their families and to lack parental acceptance and understanding.

2. In male participants, longer SNS usage times were associated with an increased need for deference.

3. Young people who spent more time using SNS were more likely to respond to a stressful situation with a sense of helplessness and resignation and to cope by downplaying the problem and seeking substitute gratification or support.

4. Young people who spent more time using SNS were more likely to respond with indirect aggression, negativism, suspicion, hostility and verbal aggression.

\section{Wstęp}

W ciągu ostatnich lat korzystanie $\mathrm{z}$ portali społecznościowych (SNS, ang. social networking sites), takich jak np.: Facebook, Twitter i Instagram, zyskało ogromną popularność i stało się dla wielu osób niezbędnym elementem każdego dnia. SNS są internetowymi serwisami, które skupiają w swoim działaniu wiele funkcji, m. in. ułatwiają komunikację, zapewniają rozrywkę, są narzędziem marketingu i źródłem informacji. Najnowsze dane wskazują, że aktywnymi użytkownikami mediów społecznościowych jest 19 milionów Polaków, czyli około połowa populacji naszego kraju, którzy - średnio 2 godziny dziennie przeznaczają na korzystanie z SNS [1,2]. Pempek i wsp. [3] ustalili, że czas, jaki uczniowie spędzają na Facebooku jest rozproszony w ciągu dnia, co może sugerować, że aktywność na Facebooku jest zintegrowana $\mathrm{z}$ ich codziennym życiem.

Podkreślić jednocześnie należy, że zwiększeniu czasu korzystania $\mathrm{z}$ Internetu, $\mathrm{w}$ tym $\mathrm{z}$ portali społecznościowych może sprzyjać aktualna sytuacja, związana $\mathrm{z}$ trwającą od roku pandemią Sars-Cov-2, ogłaszany lockdown, nauka zdalna, ograniczone bezpośrednie kontakty z rówieśnikami, spędzanie czasu głównie w domu, z członkami rodziny, który wcześniej był spędzany w szkole, z kolegami, przyjaciółmi. Bezpośrednie relacje międzyludzkie, związane zarówno z nauką, pracą, te zawodowe, jak i pozazawodowe, towarzyskie - zostały znacząco, jak nie całkowicie - ograniczone i przeniesione do Internetu. Nauczyciele, pedagodzy, psycholodzy szkolni zwracają uwagę na sytuację, gdy niektórzy uczniowie podczas lekcji wyłączają kamerki internetowe w celu grania w gry, kontaktowania się na portalach społecznościowych, czy za pomocą komunikatorów. Specjaliści podkreślają negatywne skutki ograniczenia bezpośrednich kontaktów społecznych w grupie dzieci i młodzieży oraz przeniesienia „szkoły” do Internetu. Dziecko, które do tej pory uczyło się pod nadzorem nauczyciela w szkole, teraz często pozostaje bez nadzoru i opieki w domu, gdyż rodzice w tym czasie pracują. Część rodziców stara się, aby aktualna sytuacja miała jak najmniejszy niekorzystny wpływ na ich dziecko, część uważa, że dziecko „poradzi sobie samo, jak dotychczas", czy zaniedbują dziecko, nie interesując się jego problemami. Dzieci i młodzież, które znalazły się w takiej sytuacji, odizolowane od pomocy z zewnątrz, od rówieśników, mogą szukać ucieczki od trudnej sytuacji w wirtualnym świecie, kontaktach utrzymywanych przez Internet. $\mathrm{W}$ związku $\mathrm{z}$ opisaną sytuacją, szczególnie istotne jest podejmowanie badań nad czynnikami zarówno rodzinnymi, jak i osobowościowymi, które mogą sprzyjać nadmiernemu, patologicznemu korzystaniu z portali społecznościowych.

Wiele badań poświęcono wpływowi użytkowania SNS na życie jednostki. Lanigan [4] uważa, że wciąż zbyt mało jest aktualnych badań, które wyjaśniają korelacje między korzystaniem z SNS a funkcjonowaniem rodziny, komunikacją jej członków, jakością ich relacji. Martínez-Ferrer i wsp. [5] opisują, że problematyczne korzystanie z SNS przez członków rodziny prowadzi do społecznej izolacji u młodzieży, ograniczenia lub zaburzenia komunikacji między jej członkami i wiąże się z wysokim poziomem przemocy między dziećmi a rodzicami. Ali i Lodhi [6] zwracają uwagę, że w rodzinach uczniów uzależnienionych od Facebooka obserwuje się liczne konflikty, słabsze więzi, rozpad relacji oraz 
niski stopień zainteresowania rodzeństwem. Podobnie Huisman i wsp. [7] zauważyli, że korzystanie z SNS może prowadzić do konfliktów w rodzinach. Ich zdaniem podłożem nieporozumień mogą być różnice w zakresie poglądów dotyczących roli technologii, długości czasu spędzonego na portalach społecznościowych, sposobu ich używania oraz wpływu na dzieci. Iovu i wsp. [8] wykazali, że wysoki stopień aktywności członków rodziny na Facebooku ma negatywny wpływ na poziom ich satysfakcji z życia. Przeciwnie Sharaievska i Stodolska [9] informują, że korzystanie z portali społecznościowych zwiększa satysfakcję rodziny, umożliwiając uczestnikom pozostawanie $\mathrm{w}$ kontakcie $\mathrm{z}$ dalszymi jej członkami oraz pozwala rozwijać poczucie wspólnoty.

Niewielu autorów podjęło badania, których celem była analiza typów osobowości osób, które często korzystają z SNS, a także ich motywacji do korzystania z portali. Nadkarni i Hofmann [10] uważają, że częste korzystanie z portali społecznościowych wiąże się ze zwiększonym poziomem ekstrawersji, neurotyzmu i narcyzmu, a także niskim poziomem samooceny. Użytkownicy Facebooka z wysokim poziomem ekstrawersji, którzy wyrażają wysoki poziom poczucia własnej wartości wykazywali wyższy stopień towarzyskości oraz byli członkami większej liczby grup zainteresowań na Facebooku, w porównaniu z introwertykami [11,12]. Osoby z bardzo małą liczbą kontaktów offline zazwyczaj kompensują swoją introwersję, ograniczoną liczbę relacji społecznych, niską samoocenę i niską satysfakcję z życia, korzystając z Facebooka $[13,14,15,16]$. Orr i wsp. [17] uważają, że Facebook i MySpace zapewniają nieśmiałym osobom możliwość nawiązywania interakcji społecznych, których w relacjach bezpośrednich mogłyby uniknąć. Stopień nieśmiałości jest szczególnie związany z czasem, jaki użytkownicy spędzają na Facebooku, i pozytywnie koreluje z ich postawami wobec osób, z którymi utrzymują kontakty na portalu społecznościowym. Nieśmiałość jest ujemnie skorelowana z liczbą kontaktów na Facebooku. Łatwość nawiązywania relacji zapewniana przez SNS wiąże się $\mathrm{z}$ większym zaangażowaniem czasowym osób nieśmiałych, co może skutkować nadmiernym i/ lub potencjalnie uzależniającym korzystaniem z portali społecznościowych [18]. Intensywność korzystania z Facebooka przez studentów zmniejszała postrzegany przez nich poziom samotności i pozytywnie wpływała na ich życie towarzyskie. Zwiększony czas, który użytkownicy poświęcali na aktywność na Facebooku był pozytywnie skorelowany z przyjaźniami offline [18]. Yu i wsp. [19] zaobserwowali pozytywną korelację między korzystaniem z Facebooka a poprawą samooceny u badanych studentów uniwersytetów w Chinach. Ich zdaniem korzystanie z Facebooka jest determinowane przede wszystkim nasiloną potrzebą przynależności i autoprezentacji. Potrzeba przynależności opisana jest jako motywacja do zdobywania akceptacji społecznej. $\mathrm{Na}$ tę potrzebę mogą wpływać cechy osobowości użytkowników SNS, w tym: narcyzm, neurotyczność, introwersja, ekstrawersja, poziom samooceny, poczucie własnej wartości i nieśmiałość. Poczucie własnej wartości i samoocena są ściśle związane z potrzebą przynależności i często odzwierciedlają akceptację danej osoby w grupie. Back i wsp. [20] oraz Livingstone [21] uważają, że użytkownicy Facebooka tworzą swoje profile, aby odzwierciedlić idealny obraz siebie. Potembska i wsp. [22], na podstawie wyników badań stwierdzili, że młodzież posiadająca profil na portalu społecznościowym, w porównaniu z młodzieżą nieposiadającą profilu ma bardziej negatywny obraz siebie. Chłopcy posiadający profil na SNS, w porównaniu do rówieśników nieposiadających profilu na SNS wyrażali nasiloną wrogość wobec siebie i innych osób, byli mniej pewni siebie, mieli mniejszy wgląd w motywy zachowań własnych i innych ludzi, charakteryzowali się większą impulsywnością, skłonnością do łamania zasad i norm społecznych, mniejszą odpowiedzialnością, przedsiębiorczością i wytrwałością w realizacji zadań oraz mniejszą tolerancją na frustrację. Dziewczęta posiadające profil na SNS, w porównaniu do koleżanek nieposiadających profilu na SNS miały większe trudności w radzeniu sobie ze stresem, nasiloną tendencję do ucieczki od rzeczywistości w marzenia oraz istotnie bardziej nasiloną potrzebę uzyskiwania wsparcia, poszukiwania opieki, troski, pomocy, przy czym innych ludzi postrzegały jako silniejszych, bardziej kompetentnych i skutecznych [22].

Andreassen i Pallesen [23] są zdania, że czynnikami ryzyka rozwoju uzależnienia od SNS są najprawdopodobniej cechy osobowości, potrzeby i poczucie własnej wartości. Osoby uzależnione od Internetu często mają trudności z nawiązaniem bliskich lub intymnych relacji z innymi w realnym życiu i dlatego mogą preferować korzystanie z interakcji opartych na Internecie, aby łączyć się z innymi w sposób, który nie stanowi dla nich zagrożenia [24]. Takie osoby mogą tworzyć nowe, wirtualne relacje lub pielęgnować istniejące poprzez regularne interakcje, które są możliwe dzięki częstym wizytom na portalu społecznościowym. Wirtualne społeczności, takie jak Facebook i inne SNS, często tworzą sieć wsparcia społecznościowego, co może pomóc $\mathrm{w}$ zaspokojeniu potrzeby nawiązywania relacji społecznych [25]. Osoby, które mają problemy z rozwijaniem prawidłowych relacji interpersonalnych $w$ realnym życiu, często odkrywają, że potrafią swobodnie komunikować się $\mathrm{w}$ środowisku wirtualnym oraz znajdować akceptację i towarzystwo, których im brakuje. Dlatego osoby te mogą być zmotywowane do częstszego 
korzystania z SNS jako alternatywnego sposobu rozwijania relacji społecznych [26].

Podkreślić również należy, że obecnie, w czasie ogłoszonego w Polsce i na Świecie stanu pandemii SARSCov-2, trwającego rok zdalnego nauczania, ograniczenia bezpośrednich kontaktów interpersonalnych z rówieśnikami, które przeniesione zostały głównie do Internetu oraz „zamknięcia” dzieci i młodzieży w domach, a w związku z tym zwiększenia częstotliwości relacji z rodzicami, szczególnie wartościowe mogą być badania analizujące zależności między czynnikami rodzinnymi i środowiskowymi a wydłużaniem czasu spędzanego przez młodzież na portalach społecznościowych. Wyniki tych badań mogą mieć znaczenie nie tylko teoretyczne, ale i praktyczne. Mogą być wykorzystane przy planowaniu działań profilaktycznych, zapobiegających nieprawidłowemu korzystaniu przez dzieci i młodzież z Internetu, w tym z portali społecznościowych.

\section{Cel}

Celem pracy była analiza zależności między długością czasu spędzanego przez badanych na portalu społecznościowym a czynnikami rodzinnymi i osobowościowymi (cechami obrazu siebie, sposobami radzenia sobie ze stresem i rodzajami syndromu agresji).

\section{Hipotezy}

W pracy sformułowano hipotezy badawcze:

1. Występują istotne zależności między długością czasu korzystania z portalu społecznościowego przez badanych a nadużywaniem alkoholu przez członka rodziny, doświadczaną w rodzinie przemocą i brakiem akceptacji ze strony rodziców.

2. Występują istotne zależności między długością czasu korzystania z portalu społecznościowego przez badanych a negatywnym obrazem siebie.

3. Występują istotne zależności między długością czasu korzystania z portalu społecznościowego przez badanych a poszukiwaniem zastępczej satysfakcji w konfrontacji ze stresem.

4. Występują istotne zależności między długością czasu korzystania z portalu społecznościowego przez badanych a agresją pośrednią.

\section{Materiał}

Badaniami objęto 291 uczniów gimnazjów i liceów (188 dziewcząt i 103 chłopców) w wieku od 14 do 19 roku życia. Średni wiek badanych wynosił 16,5 lat $(s d=1,48)$. Z miasta pochodziły 132 osoby a ze wsi - 159 uczniów. Do gimnazjum uczęszczało 59 dziewcząt i 44 chłopców a do liceum - 129 dziewcząt i 59 chłopców. W rodzinie pełnej wychowało się 247 osób, w rodzinie niepełnej 35, a w rodzinie zrekonstruowanej 8 osób. Wykształcenie wyższe uzyskało 42 ojców i 74 matki, a wykształcenie średnie 126 matek i 116 ojców badanych uczniów. Wykształcenie zawodowe miało 66 matek i 102 ojców, a wykształcenie podstawowe uzyskało 19 matek i 18 ojców. Aktywnych zawodowo było 213 matek i 226 ojców. Świadczenie rentowe otrzymywało 10 matek i 19 ojców, a świadczenia emerytalne - 12 matek i 6 ojców. Status osoby bezrobotnej miało 20 ojców oraz 54 matki. Wśród badanych 262 osoby posiadały rodzeństwo. Papierosy paliło 51 uczniów (w tym 34 osoby w wieku od 14 do 17 roku życia), alkohol piły 254 osoby (w tym 177 uczniów w wieku od 14 do 17 roku życia), a narkotyki stosowało 34 uczniów. 0 nadużywaniu alkoholu przez członka rodziny informowały 32 osoby. Alkoholu nadużywało 6 matek i 20 ojców.

\section{Metody}

W badaniach wykorzystano metody badawcze:

Ankietę własnej konstrukcji - na jej podstawie określono dane socjodemograficzne oraz długość czasu korzystania z portalu społecznościowego dziennie (w godzinach) oraz wykształcenie rodziców, jakość relacji w rodzinie (poczucie osamotnienia, poczucie akceptacji i zrozumienia ze strony rodziców, poczucie rozczarowania rodziców, doświadczanie przemocy psychicznej, fizycznej ze trony rodziców, doświadczanie konfliktów między rodzicami, nadużywania alkoholu przez rodziców.

Test Przymiotnikowy ACL H.G. Gougha

i A.B. Heilbruna opracowany został

w Instytucie Osobowości Uniwersytetu Kalifornijskiego. Test ACL stanowi lista 300 przy miotników i jest najczęściej wykorzystywany jako wieloskalowy test osobowości, w którym osoba badana opisuje siebie. Wersja ACL z roku 1980 składa się z 37 skal, które podzielono na pięć grup: I.Sposoby wyrażania i opisywania siebie, II.Skale potrzeb psychicznych (w oparciu o koncepcję Murraya), III.Skale tematyczne, IV.Skale analizy transakcyjnej (w oparciu o koncepcję E.Berne), V.Skale oryginalności inteligencji. Rzetelność Testu Przymiotnikowego oceniano w różnych aspektach. W grupie 100 mężczyzn, którzy wypełniali ACL dwukrotnie w odstępie ok. 6 miesięcy, indywidualne współczynniki stabilności wahały się od +0,01 do +0,54 [27]. W celu określenia rzetelności poszczególnych skal, przeprowadzono dwukrotne badania w grupie 56 mężczyzn w odstępie 10 tygodni. Uzyskane współczynniki korelacji mieściły się w granicach od 0,54 do 0,85 . W podobny sposób sprawdzono rzetelność testu ACL w tłumaczeniu polskim. Wykorzystano zewnętrzne kryteria trafności, korelując dane ACL z wynikami testów: Edwardsa Inwentarza Upodobań Osobistych, WISKAD, Testu Apercepcji Tematycznej, Kalifornijskiego Inwentarza Psychologicznego [27].

Kwestionariusz Radzenia Sobie ze Stresem autorstwa Janke, Erdman, Boucsein przetłumaczyła na język polski 
i opracowała Januszewska [28]. Kwestionariusz składa się ze 114 pytań testujących 19 wymienionych poniżej sposobów reagowania $\mathrm{w}$ sytuacji stresu: Bagatelizacja, Porównanie z innymi, Obrona przed winą, Zastępcza satysfakcja, Poszukiwanie samo potwierdzenia, Próba kontroli przebiegu sytuacji, Próba kontroli swoich reakcji, Pozytywne instruowanie siebie, Poszukiwanie społecznego wsparcia, Tendencja unikowa, Tendencja ucieczkowa, Izolowanie się od ludzi, Dalsze zajmowanie się w myślach, Rezygnacja, Użalanie się nad sobą, Obwinianie siebie, Agresja, Używanie leków lub innych związków chemicznych. Kwestionariusz opracowano na polskiej próbie, która składała się z 268 dziewcząt i 204 chłopców w wieku od 13 do 18 r.ż. Współczynnik $\alpha$ dla wszystkich 114 pytań wyniósł 0,94, a dla 19 sposobów opracowania stresu $\alpha=0,88$ [28].

Inwentarz A.H. Bussa i A. Durkee, nazywany Hostility - Gild Inventory, opracowano w roku 1957. Składa się z 75 oryginalnych stwierdzeń, spośród których 66 ocenia różne typy agresywności, wrogości, a 9 stwierdzeń jest przeznaczonych do mierzenia poczucia winy. Współczynniki rzetelności dla skal mierzących poszczególne odmiany agresywności wahały się od 0,78 do 0,61, a jedynie współczynnik rzetelności dla skali - negatywizm wynosił 0,46. Autorzy kwestionariusza oceniali trafność teoretyczną i czynnikową metody, wyodrębniając 7 odmian reakcji agresywnych, które zgrupowali w dwie klasy nazwane agresywnością i wrogością. Polską wersję kwestionariusza pt. „Nastroje i Humory" opracował M. Choynowski [29]. Kwestionariusz zawiera następujące skale: Agresja fizyczna, słowna, pośrednia, Negatywizm, Podejrzliwość, Uraza, Drażliwość, Poczucie winy. Kwestionariusz „Nastroje i Humory" może służyć do badań zarówno grupowych, jak i indywidualnych. Suma punktów w skalach I-VII stanowi wynik w skali „Agresja Ogólna.” Polskiej adaptacji Kwestionariusza dokonano na próbie obejmującej łącznie 284 osoby.

\section{Wyniki}

W pierwszym etapie analiz, na podstawie danych $\mathrm{z}$ ankiety własnego autorstwa, z całej badanej grupy 291 uczniów wyodrębniono 246 osób, które miały założony profil na portalu społecznościowym. 0 posiadaniu profilu na portalu społecznościowym informowało - z grupy 103 mężczyzn - 75, a z grupy 188 kobiet - 171 .

Celem określenia zależności między liczbą godzin spędzanych dziennie na portalu społecznościowym przez badanych a wyodrębnionymi w ankiecie własnego autorstwa czynnikami rodzinnymi, obliczono współczynniki korelacji punktowo-biseryjnej. W analizach uwzględniono podział badanych z uwagi na płeć (tabela 1). W tabeli zamieszczono wyniki istotne statystycznie.

W całej badanej grupie stwierdzono występowanie istotnych zależności między dłuższym czasem korzystania z SNS przez badanych a poczuciem osamotnienia w rodzinie, braku akceptacji i zrozumienia ze strony rodziców, głównie matki. W grupie mężczyzn otrzymano istotne zależności między dłuższym czasem korzystania

Tabela 1.Współczynniki korelacji punktowo-biseryjnej między długościq̨ czasu spędzanego na portalu społecznościowym a czynnikami rodzinnymi (dane na podstawie ankiety)

\begin{tabular}{|l|c|c|c|}
\hline Czynniki rodzinne & Cała grupa & Mężczyźni & Kobiety \\
\hline Wykształcenie ojca & $-0.28^{*}$ & $0.17^{*}$ \\
\hline $\begin{array}{l}\text { Nadużywanie alkoholu } \\
\text { przez członka rodziny }\end{array}$ & $0.14^{*}$ & & $0.17^{*}$ \\
\hline $\begin{array}{l}\text { Poczucie samotności w } \\
\text { rodzinie }\end{array}$ & $-0.21^{* * *}$ & $-0.16^{*}$ & $-0.23^{* *}$ \\
\hline $\begin{array}{l}\text { Poczucie akceptacji ze } \\
\text { strony rodziców }\end{array}$ & $-0.15^{*}$ & $-0.28^{*}$ & $0.16^{*}$ \\
\hline $\begin{array}{l}\text { Poczucie akceptacji ze } \\
\text { strony matki }\end{array}$ & & & $0.16^{*}$ \\
\hline Konflikty w rodzinie & $-0.15^{*}$ & & \\
\hline $\begin{array}{l}\text { Przemoc psychiczna ze } \\
\text { strony rodziców }\end{array}$ & & & $0.23^{* *}$ \\
\hline $\begin{array}{l}\text { Poczucie zrozumienia ze } \\
\text { strony matki }\end{array}$ & & & \\
\hline $\begin{array}{l}\text { Poczucie rozczarowania } \\
\text { matki }\end{array}$ & & & \\
\hline
\end{tabular}

Notations: ${ }^{*} p<0.05 ;{ }^{* *} p<0.01 ;{ }^{* * *} p<0.001$ 
z SNS a niższym wykształceniem ojca, poczuciem braku akceptacji ze strony rodziców i osamotnienia w rodzinie. W grupie kobiet występują znaczące zależnościach między dłuższym czasem korzystania z SNS a nadużywaniem alkoholu przez rodziców, konfliktami między nimi, doświadczaniem przemocy psychicznej z ich strony oraz poczuciem osamotnienia $\mathrm{w}$ rodzinie, braku akceptacji $\mathrm{i}$ zrozumienia ze strony matki oraz rozczarowywania jej.

W następnym etapie badań analizowano zależności między długością czasu spędzanego na portalu społecznościowymi przez badanych a czynnikami osobowościowymi: obrazem siebie, sposobami radzenia sobie ze stresem oraz rodzajami przejawianej agresji.

W tabeli 2 zamieszczono współczynniki korelacji r-Pearsona obliczone między wynikami w skalach Testu Przymiotnikowego ACL a długością czasu spędzanego na portalu społecznościowym.

Otrzymane wyniki informują o występowaniu

Tabela 2. Współczynniki korelacji między długościq̨ czasu spędzanego na portalu społecznościowym a skalami Testu ACL

\begin{tabular}{|c|c|c|c|}
\hline Skale ACL & Cała grupa & Mężczyźni & Kobiety \\
\hline $\begin{array}{l}\text { ogólna liczba wybranych } \\
\text { przymiotników }\end{array}$ & -0.02 & -0.01 & -0.02 \\
\hline $\begin{array}{l}\text { liczba przymiotników } \\
\text { pozytywnych }\end{array}$ & 0.05 & 0.04 & 0.04 \\
\hline $\begin{array}{l}\text { liczba przymiotników } \\
\text { negatywnych }\end{array}$ & -0.07 & -0.24 & 0.02 \\
\hline typowość & -0.06 & 0.02 & -0.08 \\
\hline potrzeba osiągnięć & -0.09 & -0.06 & -0.10 \\
\hline potrzeba dominacji & 0.00 & 0.02 & 0.00 \\
\hline potrzeba wytrwałości & 0.04 & 0.10 & -0.02 \\
\hline potrzeba porządku & 0.02 & 0.04 & -0.03 \\
\hline $\begin{array}{l}\text { potrzeba rozumienia siebie i } \\
\text { innych }\end{array}$ & -0.03 & -0.05 & -0.05 \\
\hline $\begin{array}{l}\text { potrzeba opiekowania się } \\
\text { innymi }\end{array}$ & 0.01 & 0.16 & -0.03 \\
\hline potrzeba afiliacji & 0.01 & 0.08 & 0.00 \\
\hline $\begin{array}{l}\text { potrzeba kontaktów } \\
\text { heteroseksualnych }\end{array}$ & 0.11 & 0.24 & 0.09 \\
\hline potrzeba ujawniania siebie & -0.07 & -0.03 & -0.05 \\
\hline potrzeba autonomii & -0.03 & -0.24 & 0.07 \\
\hline potrzeba agresji & 0.01 & -0.08 & 0.06 \\
\hline potrzeba zmiany & 0.03 & 0.09 & 0.01 \\
\hline potrzeba wsparcia & -0.01 & 0.12 & -0.05 \\
\hline potrzeba poniżania siebie & 0.02 & 0.11 & -0.08 \\
\hline $\begin{array}{l}\text { potrzeba podporządkowania } \\
\text { się }\end{array}$ & 0.11 & $0.26^{*}$ & 0.00 \\
\hline $\begin{array}{l}\text { skala gotowość na } \\
\text { poradnictwo }\end{array}$ & -0.11 & -0.16 & -0.10 \\
\hline skala samokontroli & -0.06 & -0.10 & -0.11 \\
\hline skala zaufania do siebie & 0.04 & 0.09 & 0.01 \\
\hline $\begin{array}{l}\text { skala przystosowania } \\
\text { osobistego }\end{array}$ & -0.02 & 0.12 & -0.04 \\
\hline skala idealnego obrazu siebie & 0.07 & 0.24 & 0.01 \\
\hline skala osobowości twórczej & 0.04 & -0.09 & 0.12 \\
\hline skala zdolności przywódczych & 0.02 & 0.05 & 0.03 \\
\hline skala męskości & -0.06 & -0.11 & 0.01 \\
\hline
\end{tabular}




\begin{tabular}{|l|c|c|c|}
\hline skala kobiecości & -0.02 & -0.06 & 0.03 \\
\hline skala rodzica krytycznego & -0.01 & -0.12 & 0.04 \\
\hline skala rodzica opiekuńczego & 0.01 & 0.17 & -0.05 \\
\hline skala dorosłego & -0.03 & 0.03 & -0.09 \\
\hline skala dziecka wolnego & 0.03 & 0.10 & 0.07 \\
\hline $\begin{array}{l}\text { skala dziecka } \\
\text { przystosowanego }\end{array}$ & -0.05 & 0.03 & -0.06 \\
\hline
\end{tabular}

\section{Notations: ${ }^{*} p<0.05 ;{ }^{* *} p<0.01 ;{ }^{* * *} p<0.001$}

istotnych statystycznie zależności między dłuższym czasem korzystania z SNS przez badanych mężczyzn a nasiloną potrzebą podporządkowania się.

W tabeli 3 zamieszczono współczynniki korelacji
r-Pearsona obliczone między wynikami w skalach Kwestionariusza KRS a długością czasu spędzanego na portalu społecznościowym.

Otrzymane wyniki informują o występowaniu

Tabela 3. Współczynniki korelacji między długością czasu spędzanego na portalu społecznościowym a skalami Kwestionariusza KRS

\begin{tabular}{|c|c|c|c|}
\hline Skala KRS & Cała grupa & Mężczyźni & Kobiety \\
\hline bagatelizacja & $0.14^{*}$ & 0.07 & 0.11 \\
\hline porównywanie z innymi & 0.07 & 0.04 & 0.11 \\
\hline obrona przed winą & 0.08 & 0.04 & 0.08 \\
\hline odwrócenie uwagi & -0.03 & -0.08 & -0.06 \\
\hline zastępcza satysfakcja & $0.14^{*}$ & -0.19 & $0.21^{* *}$ \\
\hline $\begin{array}{l}\text { poszukiwanie } \\
\text { samopotwierdzenia }\end{array}$ & 0.06 & -0.21 & 0.13 \\
\hline $\begin{array}{l}\text { próba kontroli przebiegu } \\
\text { sytuacji }\end{array}$ & 0.06 & -0.10 & 0.10 \\
\hline $\begin{array}{l}\text { próba kontroli swoich } \\
\text { reakcji }\end{array}$ & -0.01 & -0.08 & 0.00 \\
\hline $\begin{array}{l}\text { pozytywne instruowanie } \\
\text { siebie }\end{array}$ & 0.11 & -0.02 & 0.14 \\
\hline $\begin{array}{l}\text { poszukiwanie } \\
\text { społecznego wsparcia }\end{array}$ & $0.14^{*}$ & 0.07 & 0.10 \\
\hline tendencja unikowa & 0.02 & -0.09 & 0.00 \\
\hline tendencja ucieczkowa & 0.09 & 0.02 & 0.06 \\
\hline izolowanie się od ludzi & 0.04 & -0.10 & 0.04 \\
\hline $\begin{array}{l}\text { dalsze zajmowanie się w } \\
\text { myślach }\end{array}$ & 0.08 & -0.01 & 0.05 \\
\hline rezygnacja & $0.16^{*}$ & -0.01 & 0.13 \\
\hline użalanie się nad sobą & 0.09 & 0.01 & 0.06 \\
\hline obwinianie siebie & 0.11 & 0.11 & 0.04 \\
\hline agresja & 0.11 & -0.03 & 0.13 \\
\hline uzależnienie & 0.11 & 0.07 & 0.14 \\
\hline
\end{tabular}

Notations: ${ }^{*} p<0.05 ;{ }^{* *} p<0.01 ;{ }^{* * *} p<0.001$

istotnych zależności między dłuższym czasem korzystania z SNS a reagowaniem w sytuacji stresu bagatelizowaniem problemów, poszukiwaniem zastępczej satysfakcji, zwracaniem się do innych osób po wsparcie, pomoc, radę lub poczuciem porażki, przygnębienia, beznadziejności. Dłuższy czas korzystania z portalu społecznościowego przez badane kobiety współwystępuje z reagowaniem w sytuacji stresu czynnościami zastępczymi w formie 
jedzenia, oglądania telewizji, robienia zakupów itp. W grupie mężczyzn nie stwierdzono istotnych korelacji między analizowanymi zmiennymi.

W tabeli 4 zamieszczono współczynniki korelacji r-Pearsona obliczone między wynikami w skalach Kwestionariusza „Nastroje i Humory” BussDurkee a długością czasu spędzanego na portalu społecznościowym.

Tabela 4. Współczynniki korelacji między długościq czasu spędzanego na portalu społecznościowym a skalami Kwestionariusza BussDurkee

\begin{tabular}{|l|c|c|c|}
\hline $\begin{array}{l}\text { Kwestionariusza } \\
\text { „Nastroje i Humory” }\end{array}$ & Cała grupa & Mężczyźni & Kobiety \\
\hline agresja fizyczna & 0.09 & 0.02 & $0.25^{* *}$ \\
\hline agresja pośrednia & $0.18^{* *}$ & 0.20 & $0.18^{*}$ \\
\hline irytacja & 0.08 & 0.01 & 0.09 \\
\hline negatywizm & $0.18^{* *}$ & 0.03 & $0.25^{* * *}$ \\
\hline uraza & 0.11 & 0.05 & 0.12 \\
\hline podejrzliwość & $0.16^{*}$ & 0.21 & $0.16^{*}$ \\
\hline agresja słowna & $0.23^{* * *}$ & 0.15 & $0.25^{* *}$ \\
\hline poczucie winy & 0.06 & 0.00 & 0.04 \\
\hline Agresja wynik ogólny & $0.25^{* *}$ & 0.20 & $0.25^{* *}$ \\
\hline
\end{tabular}

Notations: ${ }^{*} p<0.05 ;{ }^{* *} p<0.01 ;{ }^{* * *} p<0.001$

Otrzymane wyniki wskazują na występowanie istotnych zależności między wydłużaniem czasu korzystania $\mathrm{z}$ portalu społecznościowego a częstym reagowaniem przez badanych agresja pośrednią, negatywizmem, podejrzliwością, wrogością oraz agresją słowną. Istotne korelacje między wymienionymi zmiennymi ujawniono $\mathrm{w}$ całej badanej grupie oraz w grupie kobiet.

\section{Materiał}

Wyniki przeprowadzonych analiz statystycznych pozwoliły na weryfikację sformułowanych w pracy hipotez badawczych. W pełni potwierdzona została hipoteza pierwsza. Wyniki otrzymane $\mathrm{w}$ całej badanej grupie informują o występowaniu istotnych zależności między dłuższym czasem korzystania z SNS przez badanych a poczuciem osamotnienia $\mathrm{w}$ rodzinie, braku akceptacji i zrozumienia ze strony rodziców, głównie matki. W grupie mężczyzn istotne zależności występują między dłuższym czasem korzystania $\mathrm{z}$ portalu społecznościowego a niższym wykształceniem ojca i poczuciem braku akceptacji $\mathrm{w}$ rodzinie. W grupie kobiet znaczące zależności występują między dłuższym czasem korzystania z SNS a nadużywaniem alkoholu przez rodziców, konfliktami między nimi, doświadczaniem przemocy psychicznej $\mathrm{z}$ ich strony, poczuciem osamotnienia w rodzinie, braku akceptacji i zrozumienia ze strony rodziców oraz rozczarowywania matki. Wyniki te korespondują z opinią innych autorów $[4,5,6]$, którzy zwracają uwagę na wysoki poziom przemocy, zaburzenia komunikacji, liczne konflikty, rozpad relacji w rodzinach osób problematycznie korzystających z SNS. W „obliczu” traumatycznych doświadczeń w kontaktach z rodzicami stosującymi przemoc, nadużywającymi alkohol, nieakceptującymi dziecka, badani mogą „uciekać” w „świat wirtualnych relacji, świat Internetu”, który pozwoli im na zaspokojenie podstawowych potrzeb psychicznych, które nie są zaspokajane w rodzinie. Kontakty nawiązywane przez SNS mogą stać się „substytutem” dla traumatycznych relacji $\mathrm{w}$ rodzinie, co sugerują wyniki badań innych autorów [22].

Częściowo potwierdzona została hipoteza druga, zakładająca występowanie istotnych zależności między długością czasu korzystania z SNS a cechami obrazu siebie. Jedynie $\mathrm{w}$ grupie badanych mężczyzn ujawniono znaczące zależności dłuższym czasem korzystania z SNS a nasiloną potrzebą podporządkowania się, przyjmowania podrzędnych ról w relacjach interpersonalnych. Można sformułować hipotezę, że osoby nieśmiałe, które mają trudności z nawiązywaniem relacji społecznych w życiu realnym mogą preferować interakcje oparte na Internecie, gdyż są sposobem komunikowania się, który nie stanowi zagrożenia [24]. Osoby te mogą tworzyć nowe wirtualne relacje lub pielęgnować już istniejące poprzez regularne interakcje, które są możliwe dzięki częstym wizytom na SNS. Społeczności wirtualne, takie jak Facebook i inne SNS, pozwalają zaspokoić potrzebę otrzymywania wsparcia społecznego [25]. Korzystając z funkcji czatu, komunikatorów internetowych lub uogólnionych postów i komentarzy, użytkownicy SNS mogą komunikować się z innymi, aby zrekompensować więzi emocjonalne, których brakuje w ich prawdziwym życiu. Subrahmanyam 
i wsp. [30] zauważają, że przyczyny społeczne stanowią najważniejszy czynnik motywujący do korzystania z SNS przez studentów. Nadkarni i Hofmann [10] stwierdzili, że korzystanie $\mathrm{z}$ Facebooka jest determinowane przede wszystkim potrzebą przynależności, akceptacji społecznej oraz potrzebą autoprezentacji. Dla osób z nasiloną potrzebą podporządkowania się, nieśmiałych Internet może być jedynym miejscem, które pozwala na wykreowanie pozytywnego obrazu siebie i nawiązanie relacji społecznych. Z opinią tą koresponduje zdanie, które wyrażają Back i wsp. [20] oraz Livingstone [21]. Uważają oni, że użytkownicy Facebooka tworzą swoje profile, aby odzwierciedlić idealny obraz siebie. Pawłowska i wsp. [31] wykazali, że motywacją do założenia profilu na portalu społecznościowym przez młodzież jest chęć utrzymywania kontaktów ze znajomymi, zdobywanie nowych informacji o znajomych oraz chwalenie się. Autorzy ci [31] informują jednocześnie, że aktywność na SNS dziewcząt łączyła się z cechami obrazu siebie: nasiloną impulsywnością, chęcią uzyskania natychmiastowej gratyfikacji, poszukiwaniem nowych bodźców i doznań większą odwagą i pewnością siebie. Aktywność chłopców na SNS łączyła się z nasiloną potrzebą przynależności i nawiązywania kontaktów heteroseksualnych [31].

Otrzymane wyniki potwierdziły w pełni hipotezę trzecią. W grupie badanych mężczyzn znaczące zależności ujawniono między dłuższym czasem korzystania z SNS a reagowaniem $\mathrm{w}$ sytuacji stresu bagatelizowaniem problemów, poszukiwaniem zastępczej satysfakcji, zwracaniem się do innych osób po wsparcie, pomoc, radę lub poczuciem porażki, przygnębienia, beznadziejności. Dłuższy czas korzystania z SNS przez badane kobiety współwystępuje z wykonywaniem w sytuacji stresu czynności zastępczych $\mathrm{w}$ formie jedzenia, oglądania telewizji, robienia zakupów itp. Czas spędzony na SNS możne być więc formą poszukiwania zastępczej satysfakcji, sposobem radzenia sobie ze stresem, który pomaga „uciec” od problemu, „zapomnieć” o nim, bagatelizować go. Podkreślić należy, że osoby patologicznie korzystające z Internetu używają go w celu „ucieczki przed problemami, zastępując rzeczywistość, która ich nie satysfakcjonuje, tym „wirtualnym”, łatwym do „wykreowania”, „internetowym światem” [22].

Otrzymane wyniki potwierdziły hipotezę czwartą i jednocześnie dostarczyły dodatkowych informacji. W całej badanej grupie oraz w grupie kobiet ujawniono występowanie istotnych zależności między wydłużaniem czasu korzystania z SNS a częstym reagowaniem agresją pośrednią, słowną, negatywizmem, podejrzliwością i wrogością. Dłuższy czas korzystania z SNS przez badane kobiety współwystępuje również z częstym ujawnianiem agresji fizycznej. Można przypuszczać, że dla dziewcząt portale społecznościowe, Internet staje się miejscem, gdzie bez cenzury, bez kulturowych ograniczeń, bez lęku przed konsekwencjami mogą wyrazić agresję, gniew, których nie mogą, nie potrafią wyrazić w sposób konstruktywny w świecie realnym.

Podsumowując wyniki badań należy podkreślić, że wydłużaniu czasu korzystania z SNS sprzyjają zarówno niesprzyjające prawidłowemu rozwojowi dzieci i młodzieży czynniki rodzinne: konflikty, przemoc, nadużywanie alkoholu przez rodziców, czy brak z ich strony akceptacji i zrozumienia, prowadzące do poczucia osamotnienia u dziecka, jak czynniki osobowościowe, głównie - nieadaptacyjne sposoby radzenia sobie ze stresem czy nasilona agresja. Analizując aktualną sytuację, związaną ze stanem pandemii i wynikającą z niej, trwającą miesiącami izolację od rówieśników, zawężenie bezpośrednich relacji do środowiska rodzinnego, codzienne, wielogodzinne korzystanie $\mathrm{z}$ Internetu przez młodzież, zarówno w celu kontynuowania nauki, jak i utrzymywania kontaktów społecznych, bardzo istotne jest zwrócenie uwagi na czynniki ryzyka rozwoju patologicznego korzystania z Internetu, w tym z SNS, a w razie potrzeby udzielenie pomocy zarówno młodzieży, jak i ich rodzicom.

\section{Wnioski}

1. Dłuższy czas korzystania z portalu społecznościowego przez młodzież łączy się $\mathrm{z}$ poczuciem osamotnienia $\mathrm{w}$ rodzinie, braku akceptacji i zrozumienia ze strony rodziców.

2. Dłuższy czas korzystania z portalu społecznościowego przez mężczyzn łączy się z nasiloną potrzebą podporządkowania się.

3. Dłuższy czas korzystania z portalu społecznościowego przez młodzież łączy się $\mathrm{z}$ reagowaniem $\mathrm{w}$ sytuacji stresu poczuciem bezradności, rezygnacji, bagatelizowaniem problemów, poszukiwaniem zastępczej satysfakcji lub wsparcia.

4. Dłuższy czas korzystania $\mathrm{z}$ portalu społecznościowego łączy się $\mathrm{z}$ częstym reagowaniem agresją pośrednią, negatywizmem, podejrzliwością, wrogością oraz agresją słowną.

\section{Conflict of interest}

The authors have declared no conflict of interest.

\section{References:}

1. Kemp S.. 2020; Digital 2020: Poland, https://datareportal.com/ reports/digital-2020-poland

2. GUS. How do we use the Internet? 2020; Warsaw 2020. https://stat.gov.pl/obszary-tematyczne/nauka-i-technikaspoleczenstwo-informacyjne/spoleczenstwo-informacyjne/ jak-korzystamy-z-internetu-2020,5,11.html\# Polish.

3. Pempek T.A., Yermolayeva Y.A., Calvert S.L. College Students' 
Social Networking Experiences on Facebook. J. Appl. Dev. Psychol. 2009; 15: 159-166.

4. Lanigan J.D. A Sociotechnological Model for Family Research and Intervention: How Information and Communication Technologies Affect Family Life. Marr. Famil. Rev. 2009; 45: 587-609.

5. Martínez-Ferrer B., Romero-Abrio A., Moreno-Ruiz D., Musitu G. Child-to-parent violence and parenting styles: Its relations to problematic use of social networking sites, alexithymia, and attitude towards institutional authority in adolescence. Psychosoc. Intervention, 2018; 27: 163-171.

6. Ali A., Lodhi R.N. How facebook addiction affects the personal life of addict students and their family: A case study of Pakistan. P. Res. J. Comm. Econom. Soc. Scienc. 2017; 11: 184-189.

7. Huisman S., Edwards A., Catapano S. The impact of technology on families. IJEPC. 2012; 2: 44-62.

8. Iovu M.B., Runcan R., Runcan P.L, Andrioni F. Association between Facebook Use, Depression and Family Satisfaction: A Cross-Sectional Study of Romanian Youth. Iran. J. Public Health. 2020; 49: 2111-2119.

9. Sharaievska I., Stodolska M. Family satisfaction and social networking leisure. J. Leisure Stud. 2017; 36: 231-243.

10. Nadkarni A., Hofmann S.G. Why Do People Use Facebook? Pers Individ Dif. 2012; 52: 243-249.

11. Ross C., Orr E.S., Sisic M., Arseneault J.M., Simmering M.G., Orr R.R. Personality and Motivations Associated With Facebook Use. Comput Human Behav. 2009; 25: 578-586.

12. Amichai-Hamburger Y., Ben-Artzi E. Loneliness and Internet Use. Comput Human Behav. 2003: 19: 71-80.

13. Barker V. Older Adolescents' Motivations for Social Network Site Use: the Influence of Gender, Group Identity, and Collective Selfesteem. Cyberpsychol Behav. 2009; 12: 209-213.

14. Ellison N.B. Social Network Sites: Definition, History, and Scholarship. J Comput Mediat Commun. 2007; 13: 210-230.

15. Zywica J., Danowski J. The Faces of Facebookers: Investigating Social Enhancement and Social Compensation Hypotheses; Predicting Facebook and Offline Popularity. J Comput Mediat Commun. 2008; 14: 1-34.

16. Mehdizadeh S. Self-presentation 2.0: Narcissism and Self-esteem on Facebook. Cyberpsychol Behav Soc Netw. 2010; 13: 357-364.

17. Orr E.S. The Influence of Shyness on the Use of Facebook in an Undergraduate Sample. Cyberpsychol Behav. 2009; 12: 337-340.

18. Lou L.L.L. Loneliness, Friendship, and Self-esteem: First-year College Students' Experience of Using Facebook. Dissertation Abstracts International: Section B: The Sciences and Engineering., 2010; 70: 7902.

19. Yu A.Y. Can Learning be Virtually Boosted? an Investigation of Online Social Networking Impacts. Comput. Educ. 2010; 55: 1494-1503.

20. Back M.D. Stopfer J.M., Vazire S., Gaddis S., Schmukle S.C., Egloff B. i wsp. Facebook Profiles Reflect Actual Personality, Not Selfidealization. Psychol Sci. 2020; 21: 372-374.

21. Livingstone S. Taking Risky Opportunities in Youthful Content Creation: Teenagers' Use of Social Networking Sites for Intimacy, Privacy and Self-expression. New Media Soc. 2008; 10: 393-411.

22. Potembska E., Pawłowska B., Perzyńska-Starkiewicz A., Dziurzyńska E., Gajewski J. Use of social networking sites by the youth in the context of personality and family variables. Curr Probl Psychiatry. 2015; 16: 144-152.

23. Andreassen C.S, Pallesen S. Social Network Site Addiction-an Overview. Curr. Pharm. Des. 2014; 20: 4053-4061.

24. Young K.S., Abreu C.N. d. Internet Addiction: a Handbook and Guide to Evaluation and Treatment. New Jersey: John Wiley \& Sons, Inc; 2010.
25. Caplan S.E., High A.C. Beyond Excessive Use: the Interaction Between Cognitive and Behavioral Symptoms of Problematic Internet Use. Comm. Res. Rep. 2006; 23: 265-271.

26. Boyd D.M., Ellison N.B. Social Network Sites: Definition, History, and Scholarship. J Comput Mediat Commun. 2007; 13: 210-230.

27. Wolińska J., Drwal R. H.G. GoughHeilbrun's Adjective Check List (ACL) in the study of self-esteem and social perception. In: Drwal R. ed. Adaptation of Personality Questionnaires. Warszawa: PWN; 1995:67-92. Polish.

28. Januszewska E. The Coping with Stress Questionnaire. Its diagnostic value and results of studies conducted among adolescents. In: Oleś P. ed. Selected Issues in Clinical and Personality Psychology. Diagnostic Methods in Children and Adolescents. Lublin: Towarzystwo Naukowe KUL; 2005:91-124. Polish.

29. Choynowski M. An Abridged Test Manual for the Moods and Humors Inventory. Warszawa: Wydawnictwo Ministerstwa Oświaty i Wychowania; 1972. Polish.

30. Subrahmanyam K., Reich S.M., Waechter N., Espinoza G. Online and Offline Social Networks: Use of Social Networking Sites By Emerging Adults. J Appl Dev Psychol. 2008; 29: 420-433.

31. Pawłowska B., Lekan M., Międlar K., Biały-Międlar K., Fijałkowska P., Landman M. Potrzeby Use of social networking sites by the youth in the context of personality and family variables. Curr. Probl. Psychiatry. 2012; 13: 263-267. Polish.

\section{Corresponding author}

Beata Pawłowska

II Klinika Psychiatrii i Rehabilitacji Psychiatrycznej Uniwersytetu Medycznego w Lublinie

Ul. Głuska 1, 20-439 Lublin

pawlowskabeata@tlen.pl

Otrzymano: 29.09.2021

Zrecenzowano: 06.10.2021, 10.10.2021

Przyjęto do druku: 03.11.2021 